10. Im $S 9 \mathbf{m}^{\mathrm{m}} \mathbf{2}$.

I I. Für Stern $p$ siehe Harv. Ann. 37 p. 8 .

I 2. Im S $8^{\mathrm{m}} .4$. Starke Verzögerung bei 7700 . Für den A.N. 4 I 6 genannten Stern $85^{\circ} \circ 34$ soll $85^{\circ} 234$ gelesen werden.

I 3. Im $\mathrm{S} 9.6$.

14. Im $\mathrm{S} 7 \mathrm{~m} 85$. Verzögerung bei 7750. Pračka setzt das Maximum I9 Tage früher (A. N. $422 \mathrm{I}$ ).

I 5. Der Verlauf der Kurve ist demjenigen der beiden vorhergehenden Maxima 6894 (A.N. 4116 ) und 7263 (A.N. 4I64) ganz ähnlich.

I6. $p-\mathrm{T}:+10^{\mathrm{s}} \mathrm{o}^{\circ}$.

17. Kurve schlängelt.

18. Im $\mathrm{S} \circ^{\mathrm{m}_{3}}$ schwächer. Das sekundäre Minimum gut verbuirgt.

I 9. Für Stern $g$ siehe Pop. Astr. VI p. 118.

20. Der Stern bleibt ein sehr schwieriges Objekt, besonders in deo schwächeren Phasen. Das A. N. 4164 mitgeteilte Maximum 7530 soll 7545 heißen; unter $T$ soll 522 anstatt 557 gelesen werden.

21. Im $S 5^{\mathrm{m}} \cdot 9$. Kleine Verzögerung vor und nach dem Maximum (bei 7650 und bei 7770).

22. Flach. J. D. unsicher.

23. Im $S 9 \cdot 4$.

24. $n-Y:-2^{\mathrm{m}} 25^{5}+12^{\prime} 14^{\prime \prime}$.

25. $j-Z:+4^{!} 6-4^{\prime} 4^{\prime \prime}$.

26. Im $\mathrm{S} 9 \mathrm{~m} \cdot 0$. Maxima und Minima sehr spitz. Kurve Utrecht, r 908 Febr. 9. sehr glatt. Der Aufstieg ist noch etwas steiler als der Abstieg. Nach meinen Beobachtungen folgt das Maximum dem Minimum nach 88 Tagen.

27. Für Stern $s$ siehe Harv. Ann. 37 S. 168.

28. $\beta-Z:-6^{5}-0: 7$.

29. $k-\mathrm{ST}: 0^{3}+92^{n}$.

30. Im $S$ 10 ${ }^{\mathrm{m}} 7$. Verzögerung bei 7730 .

31. Im $S 10 \stackrel{\mathrm{m}}{*}$.

32. Siehe A. N. 42 II.

33. Im $\mathrm{S} 9 \mathbf{m}_{3}$. Verzögerung bei 7770 .

34. J. D. unsicher, da der Stern zwischen 7740 und 7828 nicht beobachtet werden konnte.

35. Unsicherheit \pm 10 Tage. Das Minimum konnte nicht beobachtet werden, weil der Stern in den Monaten Juni und Juli zu niedrig steht.

36. Im $\mathrm{S} 10^{\mathrm{m}} \cdot 5$.

37. A. N. 4 I 16 soll anstatt: I ? >c (A. N. $3^{873)}$ gelesen werden: I ? $<b$ (Graff, Hamburg. Mitt. 8 p. 57).

38. Die Periode scheint länger als 376 Tage (A. N. 42 I ) zu sein. Aus meinen Maxima 7070,7467 und 7875 wlirde eine Periode von 402 Tagen hervorgehen.

39. Siehe A. N. $421 \mathrm{I}$. Der Stern war im $\mathrm{S} 0^{\mathrm{m}} \cdot 3$ schwächer.

40. $j-\mathrm{RZ}:-24^{3}-\mathrm{I}^{\prime}$ (roh). Starke Verzögerung vor dem Maximum, bei 7790. Aus der Kurve folgt eine Periode von 360 Tagen.

41. Unsicherheit \pm Io Tage.

\title{
Some notes on nebulae and nebulosities.
}

\section{By E. E. Barnard.}

In the work of preparation of the Milky Way photographs made at Mount Wilson in the summer of 1905 with the Bruce telescope of the Yerkes Observatory, there are shown great masses of nebulosity in a number of places in the Milky Way. This nebulosity is noticeable and in some cases is not very faint, and had been shown more or less distinctly on my early photographs, but the pure sky of Mount Wilson brought them out unmistakably. I have collected here a few notes on some of these and shall give a more complete list later.

The star BD $-19^{\circ} 4953\left(1855.018^{\mathrm{h}} 9^{\mathrm{mn}} 5^{\mathrm{s}}: 6-19^{\circ} 42: 8\right)$ of the 7.6 magnitude is unsymmetrically placed in an almost circular nebula about $20^{\circ}$ in diameter (see A.N. 3 I I I p. 233). Between this star and $\mathrm{BD}-20^{\circ} 5055$ there is a large bed of diffused nebulosity which begins half way between these stars and extends to the west as far as $-20^{\circ} 5055$. Its following edge, which is quite straight, lies in Pos. A. $150^{\circ} \pm$ and extends about $1^{\circ}$ on each side of the line between these stars, from about $18^{\mathrm{h}} 6^{\mathrm{m}}-19^{\circ} 5$ to $18^{\mathrm{h}} 12^{\mathrm{m}}-22^{\circ} \circ$. The following edge is irregular with small tufts of nebulosity projecting from it. Some $20^{\prime}$ north of $-19^{\circ} 4953$ an irregular mass of faint nebulosity streams eastward for about $1^{\circ}$. The two stars $B D-19^{\circ} 4881$ and $-19^{\circ} 494^{6}$ are closely and densely nebulous. The nebulosity about $-19^{\circ} 488 \mathrm{I}$ is somewhat extended $n f$ and $s$. They seem to be connected with the larger nebulosity surrounding $-19^{\circ} 4953$. Some of the diffused matter from the large bed extends to them from the west.

The magnificent star cloud, whose center is roughly in $1855.018^{\mathrm{h}} 18^{\mathrm{m}}-18: 5$, is remarkable for the definiteness and angularity of its south and following outlines. The east side is about $42^{\circ}$ long and is very straight. The south side is somewhat irregular and much longer. It runs south preceding for about $90^{\circ}$ and then joins the great bed of nebulous matter just described. The northern edge of this star cloud is diffused. In the cloud towards its northern edge, are two remarkable black holes. The preceding hole is in $1855.018^{\mathrm{h}} 7^{\mathrm{m}}-18^{\circ} 10^{\circ}$. The north and south dia meter of this small hole is about $13^{\prime}$ and it is about half that in width. In its center is a I $_{2}$ magnitude star with a fainter companion some $3^{\prime}$ preceding which also has a yet fainter companion north. There are a few other faint stars in the hole nearer the edges. The following edge of the hole is singularly sharp cut, as if it had been outlined with a brush and black ink, while its preceding edge is diffused and seems to slope inwards. There is some structural detail in it. The second hole is in $1855.018^{\mathrm{h}} 9^{\mathrm{m}}$ $-18^{\circ} 15^{\circ}$. This is slightly curved and narrow and stretches southerly for some $10^{\prime}$ or $12^{\prime}$. At its north end is a blacker spot or hole. The space between these holes is filled with nebulosity, the sharp cutting off of which makes the following border of the larger hole. This nebulosity runs for 
nearly $2^{\circ}$ along the north border of the great star cloud. Nebulous wisps extend from its north edge. Indeed all this region seems to be covered with a thin nebulous substratum which grows denser at the points mentioned where it is unmistakable. There is a cloud of this nebulosity mixed up with a massing of the stars in about $1855.0 \times 18^{\mathrm{h}} 9^{\mathrm{m}}-16^{\circ} 45^{\circ}$. This connects irregularly with the great star cloud. It also extends in a straggling manner towards and connects with the Omega Nebula, $M 17$.

There is a small $V$ shaped dark marking in 1855.0 $18^{\mathrm{h}} 3^{\mathrm{m}}-18^{\circ} o^{\prime}$ which is sharply defined. There is also a group of very small, definite, dark markings in $1855.017^{\mathrm{h}} 5^{6^{\mathrm{m}}}$ $-18^{\circ} 0^{\circ}$. They cover an area of about one square degree. These markings all exist in a general luminous groundwork, covering all this part of the sky. There are masses of this nebulosity farther on between $M I 7$ and $M=6$.

\section{Messior 17.}

Messier 17 - the Swan or Omega Nebula (1860.0 $\left.18^{\mathrm{h}} 12^{\mathrm{m}} 4^{2^{\mathrm{s}}}-16^{\circ} 13^{\prime} \cdot 9\right)$ is a very remarkable object and covers a very much greater space than visual observations would indicate. Its full extent north and south is $4^{\prime}$ and it is about $24^{\prime}$ broad east and west. Its brightest portion would be comprised within a circle about $15^{\circ}$ in diameter. The rest consists of faint diffusions from the south east around to the north. Preceding the brightest portion of the nebula, by about $15^{\prime}$, are two small stars involved in a small nebulosity. These stars are $B D-16{ }^{\circ} 4812$ and $-16^{\circ} 4813$ of the 9.2 and 9.4 magnitudes, whose positions are respectively for 1855.0

$$
\begin{array}{rlrl}
\alpha & =18^{\mathrm{h}} \times 1^{\mathrm{m}} 18^{\mathrm{s}} \mathrm{I} & \delta & =-16^{\circ} 4: 2 \\
& =18 \times 147.6 & =-164.3 .
\end{array}
$$

\section{Messier 16.}

Messier 16 which is described in Dreyer's NGC. as , $\mathrm{Cl}$, at least 100 st $\mathrm{L} \& \mathrm{~S} \&$ and whose position for 1860.0 is $18^{\mathrm{h}} 10^{\mathrm{m}} 57^{\mathrm{s}}-\mathrm{r} 3^{\circ} 50^{\circ} .0$, is a beautiful object. It is a bright nebula very closely resembling the great Nebula of Orion, and is mixed up in a scattering cluster of stars. The brightest portion of it is about as large as that of $M I 7$. A bay in the north edge very much resembles that in the Orion Nebula. From each side of this bay, wing like extensions run north following and south preceding for considerable distances. Faint extensions give it a diameter of nearly one degree. Dreyer does not mention any nebulosity in connection with this group of stars. In reality the nebula itself is the main thing. ${ }^{1}$ )

\section{Messier 8.}

$$
1860.0 \quad \alpha=17^{\mathrm{h}} 55^{\mathrm{m}} 6^{\mathrm{s}} \quad \delta=-24^{\circ} 22: 8 \text {. }
$$

This beautiful nebula and mixture of bright stars is a very extraordinary object, full of rich details, among which are a number of very black, small, sharply defined spots or holes. The stars are apparently freely mixed in the nebulosity. Though there are masses of greater density in the nebula, there is nowhere any appearance of condensation about the individual stars. This is a very singular feature often noticed in connection with these mixtures of nebu. losity and stars. The stars apparently are freely mixed with the nebulosity without being centers of condensation. Of course one could avoid any attempt to explain why this should be so, by saying that the stars may not be in the nebula, but apparently so only by projection in the same direction. There are other reasons, however, which would lead one to believe that the stars and nebulosity of $\mathbf{M} 8$ are actually mixed together. Therè are too many other cases of this kind to suppose that their association is a matter of perspective. In A. N. $3111, \mathrm{Bd} .130$, p. 234 , I have given a sketch of a group of nebulae, $11 / 2^{\circ}$ following $M$ 8. In that paper it is said , The singular mixture of stars and nebulosity, $M 8$, is shown on several of the photographs [in 1892 ], and is a very remarkable object. East and west its diameter is about $45^{\circ}$, and north and south some $42^{\circ}$. The southern side is sharply defined and serrated with three distinct pointed projections. From its north following corner, a wisp of nebulosity extends nearly to the group of nebulous stars just mentioned, and possibly with a longer exposure would be found to connect with them.

The photographs of this region made with the ro-inch Bruce telescope in the splendid atmosphere of Mount Wilson in r905, show that the fainter extensions of M 8 do reach to and envelop this group of nebulae. A faint diffusion of nebulosity from the eastern side of $M 8$ covers all the space between the larger nebula and the group of nebulous stars. At the latter it becomes denser over a region as large as that of the brighter part of $M$. It seems to condense rather strongly at the several stars shown in the sketch referred to in A. N. 3 III. The star Gou 24695 of $71 / 2$ magnitude is the center of a larger but very diffused condensation. The nebula NGC. 6559 brushes out south following and has a short nebulous strip attached north preceding. The two nebulosities shown in the north preceding part of the sketch, are very striking features on the photographs. They are simply stronger condensations in the diffused mass that involves all this region. Between these two is a vacant space, or black hole, which is sharply curved and well defined on its preceding edge. The plates of this region on 1905 July 26 and 27 show the planet Uranus in the middle of this small vacancy. Slightly north following a line drawn on the sketch, between the two snovaes nebulae, the diffused nebulosity involving the group extends for a considerable distance north preceding.

There is a conspicuous small nebula or nebulous star in the position $1860.018^{\mathrm{h}} 0^{\mathrm{m}} 35^{\mathrm{s}} \pm-23^{\circ} 26^{\circ} \pm$ and another in $1860017^{\mathrm{h}} 59^{\mathrm{m}} 4^{\mathrm{s}} \pm-23^{\circ} 25^{\prime} \pm$. There is a small elongated bright nebula in the position 1860.0 $17^{\mathrm{h}} 59^{\mathrm{m}} 25^{\mathrm{s}} \pm-23^{\circ} 53^{\circ} \pm$.

The entire length of M 8 east and west is $77^{\prime}$ and north and south $45^{\prime}$. But if we reckon the faint diffused portion which extends to the group of nebulous stars to the east, the entire extension of $M 8$ would cover a space of about $2^{\circ}$ east and west.

1) Vergl. A. N. 174.28 und I. Roberts, Photographs of Stars, Star Clusters, and Nebulae, Vol. II p. I5I. Kb. 
The Trifld Nebula M 20.

$1860.0 \quad 17^{\mathrm{h}} 53^{\mathrm{m}} 54^{\mathrm{s}} \quad-23^{\circ}{ }^{1}: 5$.

This singular object has faint extensions which $I$ have not seen on any other photographs. The northern side reaches out beyond and involves the 6.3 magnitude star CoD - $22^{\circ}{ }_{1244} \quad\left(1875.0 \quad 17^{\mathrm{h}} 54^{\mathrm{m}} 20^{\mathrm{s}} \cdot 5-22^{\circ} 45^{\circ} 9\right)$ and

Yerkes Observatory, Williams Bay, Wisconsin, r 908 Jan. $3^{\circ}$. also extends for quite a distance eastward of it. There is likewise a large extension from the west side and also to the south east. The greatest diameter, including the faint outer parts, is $3^{\circ}$ in a south east and north west direction. The numerous black lanes that have made this nebula celebrated, are beautifully shown in the photographs.

\section{Die Veränderlichkeit der Radialbewegung von $\beta$ Ursae majoris.}

Die Ausmessung der von Prof. Eberhard und mir in den letzten Jahren aufgenommenen Spektrogramme von $\beta$ Ursae majoris ergab, da $\mathbb{B}$ die Radialbewegung dieses Sterns veränderlich ist. Das Spektrum gehört der Klasse $I a_{2}$ an, und in dem bei unsern Aufnahmen in betracht kommenden Spektralbezirk ist nur die $M g$-Linie $\lambda_{448 \mathrm{I}}$ gut meßbar, während die $H \gamma$-Linie wegen ihrer Breite und die übrigen, wenig zahlreichen Linien wegen ihrer großen Schwäche meist nur ungenaue Einstellungen gestatten. Die im folgenden angeführten Werte der Radialgeschwindigkeit $v$ sind daher mit beträchtlichen Unsicherheiten behaftet, durch welche allein indessen die großen Unterschiede zwischen den einzelnen Werten nicht erklärt werden können. Die Ergebnisse meiner Messungen sind:

Potsdam, Astrophysikalisches Observatorium, r 908 Febr. 27.
E. E. Barnard.

Nachschrift von März 11. Weitere Beobachtungen ergeben, daß die Periode $27^{\mathrm{d}}$ beträgt, und daß die Geschwindigkeitskurve derjenigen von $\beta$ Arietis und von $\vartheta$ Aquilae ähnelt.

H. $L$.

\section{Observations of a moving object}

near Jupiter from photographs taken at the Royal Observatory, Greenwich.*)

On examining a photograph of Jupiter VII taken on places obtained. These include and supersede those places I 908 February 28 an object of an apparent planetary nature was noticed near Jupiter VI. On reference to earlier photographs the object was identified and traced back to Jan. 27.

Provisional measures were made and the following on Jan. 27 and Febr. 28 already telegraphed which were slightly erroneous. The positions will be determined with greater accuracy later on in conjunction with Jupiter VI and Jupiter VII.

\begin{tabular}{|c|c|c|c|c|c|}
\hline \multirow{2}{*}{1908} & \multirow{2}{*}{ Gr. M. T. } & \multirow{2}{*}{ app. $\alpha$} & \multirow{2}{*}{ app. $\delta$} & \multicolumn{2}{|c|}{ Object-Jupiter } \\
\hline & & & & $\Delta \boldsymbol{\alpha}$ & $\Delta d^{\prime}$ \\
\hline Jan. & $12^{\mathrm{h}} 44^{\mathrm{m}} 9^{\mathrm{s}}$ & $8^{\mathrm{h}} 45^{\mathrm{m}} 5^{\mathrm{r}^{\mathrm{s}} \cdot 7^{8}}$ & $+18^{\circ} 5^{\circ} \quad 3^{\prime \prime} \cdot 2$ & $-0^{m} \quad 8^{s} \cdot 32$ & $-43^{\prime}$ I 5.8 \\
\hline Febr, I & I I 52 & $\begin{array}{lll}8 & 43 & 20.49\end{array}$ & +181735.7 & 2.01 & -4141.7 \\
\hline 3 & 102720 & $\begin{array}{lll}8 & 42 & 21.99\end{array}$ & +182225.2 & 6.47 & $-4 I$ \\
\hline 22 & $10 \quad 56 \quad 34$ & $\begin{array}{lll}8 & 33 & 35.4^{8}\end{array}$ & $5 \quad 48.9$ & to 48.45 & -3359.0 \\
\hline 23 & $\begin{array}{lll}8 & 33 & 49\end{array}$ & $\begin{array}{lll}8 & 33 & 14.23\end{array}$ & 736.6 & $+050.5^{6}$ & $\begin{array}{ll}-33 & 36.7\end{array}$ \\
\hline 24 & $12 \quad 2453$ & $\begin{array}{lll}8 & 32 & 47.26\end{array}$ & 951.2 & +o 53.04 & -33 \\
\hline 27 & 10 $59 \quad 24$ & 83142.99 & +191517.9 & 0.04 & -3 I 59.8 \\
\hline 28 & $\begin{array}{lll}11 & 28 & 37\end{array}$ & 83121.67 & +1917 & 2.26 & -3136.6 \\
\hline
\end{tabular}

Royal Observatory, Greenwich, I 908 March 9.

P. H. Cowell

for the Astronomer Royal.

*) Das Objekt ist, wie schon in Nr. 4237 geschehen, vorläufig als I $908 \mathrm{CJ}$ zu bezeichnen. $K b$.

1908 CJ. (Telegramm aus Cambridge, Mass., vom 17. März.) Campbell telegraphs Greenwich object near Jupiter observed by Albrecht 1908 March 8.8486 Gr. m. t. $\alpha(08.0)=8^{\mathrm{h}} 28^{\mathrm{m}} 33^{\mathrm{s}} 2 \delta(08.0)=+19^{\circ} 39^{\prime} \mathrm{I} \mathrm{I}^{\prime \prime}$. Aitken observed visually magnitude 15 . Pickering. 